\title{
DNA delivery via cationic solid lipid nanoparticles (SLNs)
}

\author{
3 Q1 Carolina Carrillo ${ }^{\mathrm{a}, *}$, Noemí Sánchez-Hernández ${ }^{\mathrm{b}}$, Encarna García-Montoya ${ }^{\mathrm{c}}$, Pilar Pérez-Lozano ${ }^{\text {, }}$, \\ 4 Josep M. Suñé-Negre ${ }^{c}$, Josep R. Ticó ${ }^{c}$, Carlos Suñé ${ }^{b}$, Montserrat Miñarro ${ }^{c}$ \\ ${ }^{a}$ Faculty of Pharmacy, University of Barcelona, Avda Joan XXIII s/n, 08028 Barcelona, Spain \\ ${ }^{\mathrm{b}}$ Instituto de Parasitología y Biomedicina López-Neyra, CSIC, Granada, Spain \\ ${ }^{\mathrm{c}}$ Faculty of Pharmacy, University of Barcelona, Spain
}

\section{A R T I C L E I N F O}

\section{Article history:}

Received 21 May 2012

Received in revised form 17 January 2013

Accepted 4 February 2013

Available online $\mathrm{xxxx}$

\section{Keywords:}

Non-viral vectors

Lipoplexes

Gene therapy

Solid lipid nanoparticles

Cationic nanoparticles

Drug delivery systems

\begin{abstract}
A B S T R A C T
In recent years the use of solid lipid nanoparticles (SLNs) as transport systems for the delivery of drugs and biomolecules has become particularly important. The use of cationic SLNs developed by the technique of microemulsion, which are complexed with DNA in order to study their application as non-viral vectors in gene therapy, is reported. The nanoparticles are characterized by scanning electron microscopy and transmission electron microscopy (SEM and TEM), atomic force microscopy (AFM) and differential scanning calorimetry (DSC). Furthermore, the process of lyophilization of the samples and their stability was studied. The nanoparticles obtained presented a particle size of $340 \mathrm{~nm}$ with a positive surface charge of $44 \mathrm{mV}$ and the capability of forming lipoplexes with DNA plasmids was stated.
\end{abstract}

(c) 2013 Published by Elsevier B.V.
Q2 * Corresponding author. Tel./fax: +34934024546.

E-mail addresses: carolinacarrillo@ub.edu (C. Carrillo), noemisanchez@ipb. csic.es (N. Sánchez-Hernández), encarnagarcia@ub.edu (E. García-Montoya), perezco@ub.edu (P. Pérez-Lozano),jmsune@ub.edu (J.M. Suñé-Negre),jrtico@ub. edu (J.R. Ticó), csune@ipb.csic.es (C. Suñé), minarromontse@ub.edu (M. Miñarro). trix of hydrophobic lipids that are solid at room and body temperatures.

SLNs have experienced constant development over recent years as drug delivery systems, although there is not much literature concerning their application in gene therapy. Their capacity to transfect cells in vitro has been demonstrated (Olbrich et al., 2001; Tabatt et al., 2004; del Pozo-Rodríguez et al., 2008, 2010; Martins et al., 2012) since the 1990s when Müller (1991) and Gasco (1993) first studied the proprieties of SLNs in drug delivery.

SLNs were originally designed as an alternative to liposomes and emulsions. Although liposomes present a series of advantages (encapsulation of both hydrophilic and hydrophobic active ingredients, reduced toxicity and increased therapeutic efficiency of active ingredients that is not achieved with other systems), their application has seen only limited success (Borchard, 2001). Such limitations are due to the complexity associated with the process of obtaining liposomes, scaling difficulties, their limited stability and the high cost of their formulation (Joshi and Müller, 2009). SLNs have the advantages of colloidal systems of drug delivery, such as liposomes, polymeric nanoparticles and emulsions, while at the same time they considerably minimize or reduce the inconveniences associated with these systems. Some of their advantages include the ability to integrate both hydrophilic and hydrophobic drugs as well as the ability to prolong active ingredient release or to immobilize it in the solid matrix. These SLNs properties compared to polymeric nanoparticles are based on their low cytotoxicity, high capacity for transfection, better stability in biological

0928-0987/\$ - see front matter (c 2013 Published by Elsevier B.V.

http://dx.doi.org/10.1016/j.ejps.2013.02.011 
systems and improved scalability (Blasi et al., 2007; Wissing et al., 2004; Marengo et al., 2000; Müller et al., 2000; Wang et al., 2012).

Gene therapy is the set of techniques by means of which fragments of DNA or RNA can be delivered to the inside of specific cells in order to modulate the expression or suppression of the biosynthesis of specific altered proteins so as to reverse a biological disorder and treat disease (Ledley, 1996; Corsi et al., 2003).

Gene delivery systems include both viral and non-viral vectors. A wide variety of vectors for the delivery of genetic material have been studied (Nishikawa and Hashida, 2002). Viral vectors are one of the strategies more generally used and are the dominant systems for gene delivery with high transfection efficiency. However, viral vector applications are limited due to the adverse effects associated with them such as their immunogenicity and oncogenicity (Wu and Ataai, 2000; Richardson et al., 1999; De Laporte et al., 2006). These limitations have led to the development of effective synthetic systems for delivering DNA incorporating the DNA in nanoparticles while aiming to maintain the advantages of viral vectors.

A large number of non-viral vectors have been studied and applied as non-natural systems of stable transfection that contain low toxicity and are non-immunogenic since they can auto-assemble with the DNA and form nanoparticles capable of being transported to the cells (Davis, 2002; He et al., 2010; Ewert et al., 2005; Li and Huang, 2007; Ferrer-Miralles et al., 2008; Rogers and Rush, 2012; Liang et al., 2012).

Non-viral vectors include cationic lipids. The electrostatic interaction between the negative charges of the DNA and the positive charges of the lipid allow the formation of a complex called lipoplex. These lipoplexes can form a structure that protects the DNA and which is able to direct it towards the target cells (Pedersen et al., 2006; Faneca et al., 2002; del Pozo-Rodríguez et al., 2007; Duarte et al., 2012).

Our purpose is to develop a method for obtaining cationic SLNs capable of forming a complex with DNA plasmids. A series of characteristics for the particles to be considered good non-viral vector are required. On the one hand, they must be nanometric in size with a suitable surface charge to form complexes with DNA plasmids, and on the other hand they must be stable.

\section{Materials and methods}

\subsection{Materials}

Stearylamine (Sigma-Aldrich ${ }^{\circledR}$, Barcelona, Spain), 2-methyloxirane as a hydrophilic non-ionic surfactant $\left(\right.$ Poloxamer $^{\circledR} 188-$ BASF $^{\circledR}$, Germany), glycerol distearate $\left(\right.$ Precirol $^{\circledR}$ ATO-5-Gattefosé ${ }^{\circledR}$, France), trehalose (Cerestar ${ }^{\circledR}$, Barcelona, Spain), mannitol (Fagron $^{\circledR}$, Barcelona, Spain). The media used are DMEM (Dulbeco's Modified Eagle's Medium, PAA ${ }^{\circledR}$ Laboratories, Austria), DMEM supplemented with penicillin $(100 \mathrm{U} / \mathrm{ml})$ and streptomycin $(100 \mu \mathrm{g} / \mathrm{ml})$ (Invitrogen $^{\circledR}$ ) and HBS (Hepes buffered saline, Sigma-Aldrich ${ }^{\circledR}$, Barcelona, Spain). The plasmid DNA used is pMS2-TCERG1 plasmid of approximately seven kilobases that contains the cDNA encoding the carboxyl region of the human transcription factor TCERG1 (Suñé et al., 1997), purified with Qiagen ${ }^{\circledR}$ kits (Hilden ${ }^{\circledR}$, Germany).

\subsection{Methods}

\subsubsection{Obtaining the SLNS}

To obtain cationic SLNs, a modification of the method described has been used (Vighi et al., 2007; Bondi' et al., 2007). The SLNs are obtained from a microemulsion (O/W) using Precirol ATO-5 and stearylamine as the cationic lipid. $500 \mathrm{mg}$ of Precirol ATO-5 is heated to $10^{\circ} \mathrm{C}$ above its melting point, and $10 \mathrm{ml}$ of a hot aqueous solution of poloxamer and stearylamine in different proportions $(1 / 1.25 ; 1 / 1.87 ; 1 / 3.12 ; 1 / 4.37$ and $1 / 5$ respectively) is added. The sample is stirred for $30 \mathrm{~min}$ at $14,000 \mathrm{rpm}\left(\mathrm{IKA}^{\circledR} \mathrm{T} 25\right.$ digital Ultra$\operatorname{Turrax}^{\circledR}$, Staufen, Germany). The nanoparticles are obtained by dispersing the hot microemulsion in cold water (between $2{ }^{\circ} \mathrm{C}$ and $5{ }^{\circ} \mathrm{C}$ ) in an emulsion:water ratio of 1:5. To recover nanoparticles, the resultant suspension is centrifuged for three times at $3000 \mathrm{rpm}$ for $20 \mathrm{~min}$ at a temperature of $20^{\circ} \mathrm{C}$, reconstituting the precipitate after centrifugation. Part of the fresh sample is then stored at $4{ }^{\circ} \mathrm{C}$, while the other part of the sample is lyophilized.

\subsubsection{Lyophilization of samples}

Cationic SLNs are lyophilized by being added an aqueous solution of cryoprotectant in the proportion 1:2 (SLN:cryoprotectant). Mannitol and trehalose are the cryoprotectants used in the study (of $5 \%$ and $10 \%$ in both cases). The freezing temperature is set at $-40{ }^{\circ} \mathrm{C}$ in the lyophilizer Telstar ${ }^{\circledR}$ L-3 $\left(\right.$ Telstar $^{\circledR}$, Terrassa, Spain), and samples are kept at this temperature for $2 \mathrm{~h}$. Lyophilization temperature is then set to $25^{\circ} \mathrm{C}$ at a pressure of $0.2-0.4 \mathrm{mBa}$ for $48 \mathrm{~h}$.

\subsubsection{Determination of particle size}

The distribution of the particle size of the cationic SLNs is determined by laser diffraction technique (Mastersizer ${ }^{\circledR} 2000$, Malvern Instruments $\left.{ }^{\circledR}, \mathrm{UK}\right)$, by dispersing the sample with bidistilled water in the Hydro dispersion module (Malvern Instruments ${ }^{\circledR}$, UK). Particle size is determined in triplicate, and the mean value is calculated. The size data are evaluated using the following distribution volumes: d10\%, d50\% and d90\% (European Pharmacopoeia, 2012).

\subsubsection{Determination of surface charge}

Particles zeta-potential values are determined by using the light dispersion technique with Zetasizer ${ }^{\circledR}$ Nano Z equipment (Malvern Instruments $\left.{ }^{\circledR}, \mathrm{UK}\right)$. An amount of sample is placed in the capillary cell for samples in aqueous media at a predetermined temperature of $25^{\circ} \mathrm{C}$. Surface charge is measured three times and the mean value taken.

\subsubsection{Electron microscopy and atomic force microscopy (AFM)}

The morphology of the cationic SLNs is studied by electron microscopy both scanning electron microscopy (Hitachi ${ }^{\circledR}$ S-2300, Japan) and transmission electron microscopy (Hitachi ${ }^{\circledR} 800 \mathrm{MT}$, Japan), and in this way their shape and size are characterized.

Atomic force microscopy (AFM) is used to study the topography of the samples: their morphology and their particle size. Extended Multimode equipment is used for the AFM with Nanoscope ${ }^{\circledR}$ IV (Veeco ${ }^{\circledR}$, Mannheim, Germany) and images are captured in Peak Force mode. A silicon nitride cantilever probe with silicon oxide tips of $0.35 \mathrm{nN} / \mathrm{nm}\left(\mathrm{SNL}-10\right.$, Bruker $^{\circledR}$, USA) is used.

\subsubsection{Differential scanning calorimetry (DSC)}

The thermal stability of the compounds is studied using the differential scanning calorimetry (DSC) equipment DSC-822e/700 (Mettler Toledo ${ }^{\circledR}$, Spain) at temperatures of between $30^{\circ} \mathrm{C}$ and $300{ }^{\circ} \mathrm{C}$ for $30 \mathrm{~min}\left(10^{\circ} \mathrm{C} / \mathrm{min}\right)$. Between 2 and $5 \mathrm{mg}$ of each of the components of the formulation is individually subjected to DSC, together with binary and tertiary mixtures of them, and also both lyophilized and fresh (non-lyophilized) SLNs.

\subsubsection{Stability}

The study of stability is carried out by preparing the samples in hermetically sealed glass vials at a temperature of $30^{\circ} \mathrm{C} \pm 2{ }^{\circ} \mathrm{C}$. Samples' morphology and appearance are then analyzed together with the $\mathrm{pH}$ and the superficial charge of the nanoparticles at different times: $t=0 ; 24 \mathrm{~h} ; 10$ days and 30 days in order to detect physical or chemical changes (Mora-Huertas et al., 2010). The 
culture media used to test stability are DMEM, DMEM with antibiotics (DMEM-Ab) and HBS.

\subsubsection{Formation of the SLN-plasmid DNA complex}

A solution of plasmid DNA is prepared to a concentration of $2 \mu \mathrm{g} / \mu \mathrm{l}$. Then $25-\mu \mathrm{l}$ aliquot of the plasmid DNA solution is added to different volumes of a suspension of the cationic SLNs to obtain ratios of between 15:1 and 1:1 (SLN:DNA) by stirring (del PozoRodríguez et al., 2008). SLN-plasmid DNA complex is formed as shown in Fig. 1.

\subsubsection{Agarose gel electrophoresis}

The interaction of nanoparticles with the plasmid DNA is studied via the electrophoretic mobility of the samples in agarose gel. After a 30 min period of incubation, the loading efficiency of the nanoparticles to encapsulate the DNA is evaluated by using the DNA pattern that depends on the quantity of plasmids that remain free in the agarose gel.

For the DNA electrophoretic gel separations, agarose D-1 Media EEO (Pronadisa ${ }^{\circledR}$ ) $0.8 \%$ in Tris-acetate-EDTA (TAE) $1 \mathrm{X}$ (Tris acetate $40 \mathrm{mM}$, EDTA $1 \mathrm{mM}$ ) with $0.5 \mu \mathrm{g} / \mathrm{ml}$ of ethidium bromide is used. Power sources, cuvettes and accessories are all from BioRad ${ }^{\circledR}$. The 6X loading buffer used consists of $0.25 \%(\mathrm{p} / \mathrm{v})$ bromophenol blue, $0.25 \%$ xylene cyanol FF and 30\% (v/v) glycerol. The molecular weight marker used is a $1 \mathrm{~kb}$ DNA ladder from New England BioLabs ${ }^{\circledR}$. Once resolved in the agarose gels, samples are visualized in a Gel Doc (BioRad ${ }^{\circledR}$ ) station using the QuantityOne ${ }^{\circledR}$ program for gels stained with ethidium bromide.

\section{Results and discussion}

After the cationic SLNs was obtained using the microemulsion method described above, the nanoparticles were characterized, the lyophilized samples studied and the stability was assessed with the below detailed results.

\subsection{Size and zeta-potential of the nanoparticles}

For the characterization of the SLN formulations, an initial study was performed by varying the quantity of stearylamine. Once several particle size and zeta-potential results were obtained (between $342-442 \mathrm{~nm}$ and $43-59 \mathrm{mV}$ ), it was observed that nanoparticles obtained with stearylamine:poloxamer proportions $1: 1.25$, had a better size-charge relationship; smaller cationic SLNs with a higher zeta-potential were obtained (Table 1). Therefore, this proportion was chosen as the working formulation.

\subsection{Lyophilization process}

Part of the fresh cationic SLNs obtained by microemulsion was diluted with the different cryoprotectants prior to being lyophilized. Before lyophilization, the particle size of the different suspensions was determined with the results shown in Table 2 . The particle sizes were between 250 and $330 \mathrm{~nm}$, approximately.

Once the process of lyophilization was complete, the visual appearance of the vials was analyzed. In all the samples containing
Table 1

Average results $( \pm \mathrm{SD} ; n=3)$ of the size and zeta-potential of the SLNs (stearylamine:poloxamer proportions $1: 1.25)$.

\begin{tabular}{ll}
\hline Particle size $(\mathrm{nm})$ & Zeta-potential $(\mathrm{mV})$ \\
\hline $342.3 \pm 0.076$ & $43.98 \pm 1.58$ \\
\hline
\end{tabular}

\section{Table 2}

Particle size for SNL samples with cryoprotectant before lyophilization, lyophilizated samples with different cryoprotectant reconstituted with water but no sonication and lyophilizated samples with cryoprotectant reconstituted with both water and sonication.

\begin{tabular}{llll}
\hline Cryoprotectant & $\begin{array}{l}\text { Particle size } \\
\text { before } \\
\text { lyophilization } \\
(\mathrm{nm})\end{array}$ & $\begin{array}{l}\text { Water + stirring } \\
(\mu \mathrm{m})\end{array}$ & $\begin{array}{l}\text { Water + sonication } \\
(\mu \mathrm{m})\end{array}$ \\
\hline Trehalose 10\% & $325 \pm 0.04$ & $0.338 \pm 0.06$ & $0.309 \pm 0.005$ \\
Mannitol 10\% & $269 \pm 6.65$ & $58.69 \pm 4.91$ & $30.446 \pm 3.33$ \\
Trehalose 5\% & $252 \pm 6.43$ & $12.64 \pm 1.19$ & $0.264 \pm 0.007$ \\
Mannitol 5\% & $296 \pm 10.21$ & $43.13 \pm 2.79$ & $22.41 \pm 0.44$ \\
SLN & $252 \pm 1.15$ & $-{ }^{\mathrm{a}}$ & $-^{\mathrm{a}}$ \\
\hline
\end{tabular}

a In the SLN samples without a cryoprotectant, particle size values could not be stated due to the formation of agglomerations.

cryoprotectant, the lyophilized tablet was observed to be in perfect condition while for the vials that contained the cationic SLNs sample without any cryoprotectant, the tablet was broken and/or moved due to possible microboiling.

Particle sizes were determined by resuspending the lyophilized samples in bidistilled water followed by stirring for a few seconds (Table 2). The best results were observed for the samples that contained the trehalose as a cryoprotectant, specifically at a concentration of $10 \%$, with a particle size that was practically the same as that of the initial sample. After 2 min of sonication, the same sample yielded a slightly smaller particle size: approximately $310 \mathrm{~nm}$.

For the samples containing trehalose at $5 \%$, and after sonication, a nanometric particle size was also observed, while for the samples containing the mannitol cryoprotectant, the resultant particle size was never below $20 \mu \mathrm{m}$, irrespective of the concentration.

Resuspension of the cationic SLNs with no cryoprotectant proved to be quite difficult, even after more than 20 min of sonication; agglomerates of several micrometres $(30-40 \mu \mathrm{m})$ were formed. This behavior indicated that the sample had become degraded due to possible microboiling during the lyophilization process.

\subsection{Electron microscopy and AFM}

Electron microscope images are shown in Fig. 2a-d. The cationic SLNs appear as smooth spheres with a size similar to that obtained by laser diffraction.

Morphology and particle size were analyzed by topography through the AFM images of the cationic SLNs as shown in Fig. 3. Particles seemed to be polydisperse and in order to determine the particles size, a number of independent particles were chosen
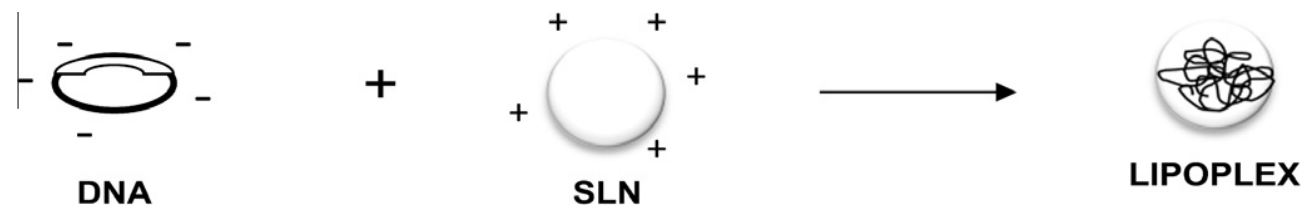

Fig. 1. Representative structure for condensed plasmid DNA on the outside of the cationic SLNs (lipoplex) formed through electrostatic interactions. 

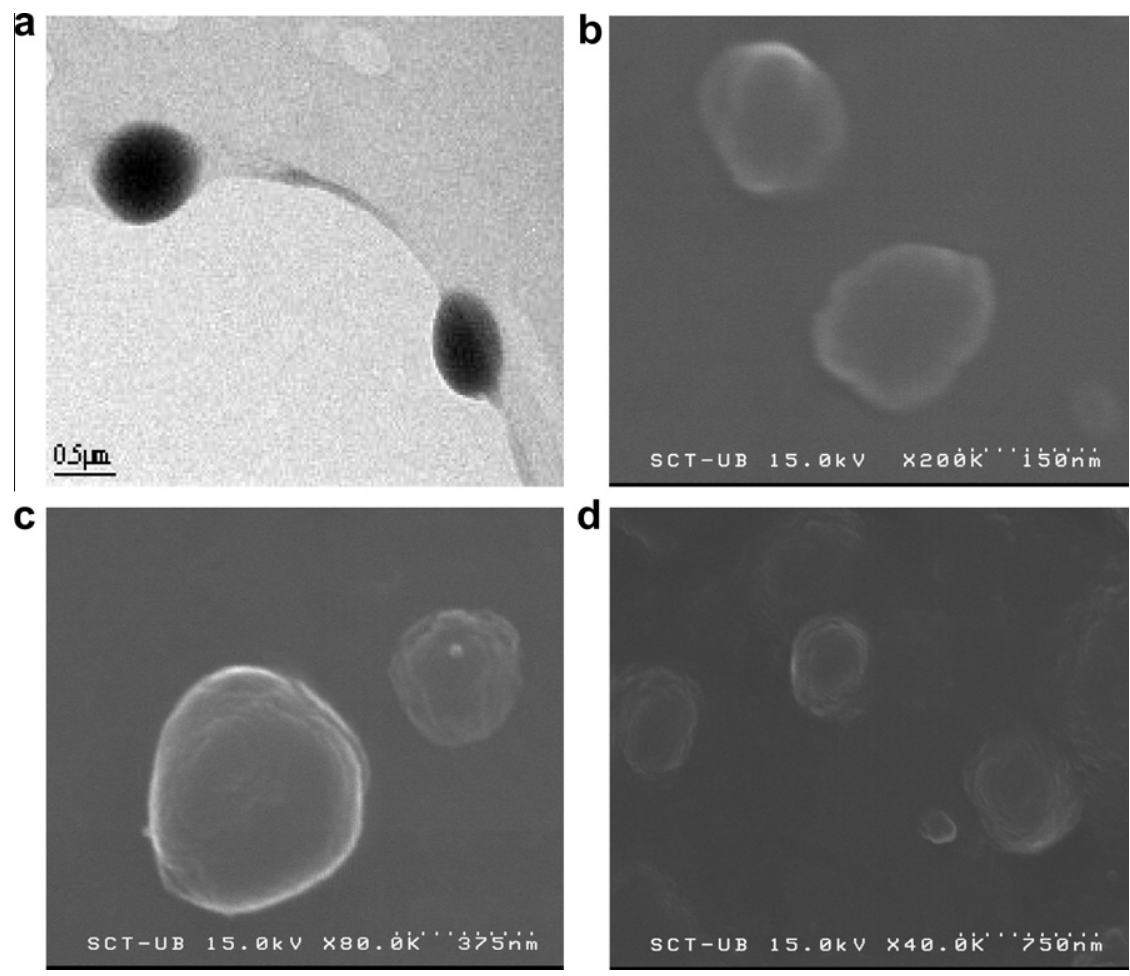

Fig. 2. Electron microscope photographs of SLNs (before lyophilization): by transmission electron microscopy (2a) and by scanning electron microscopy (2b-2d).

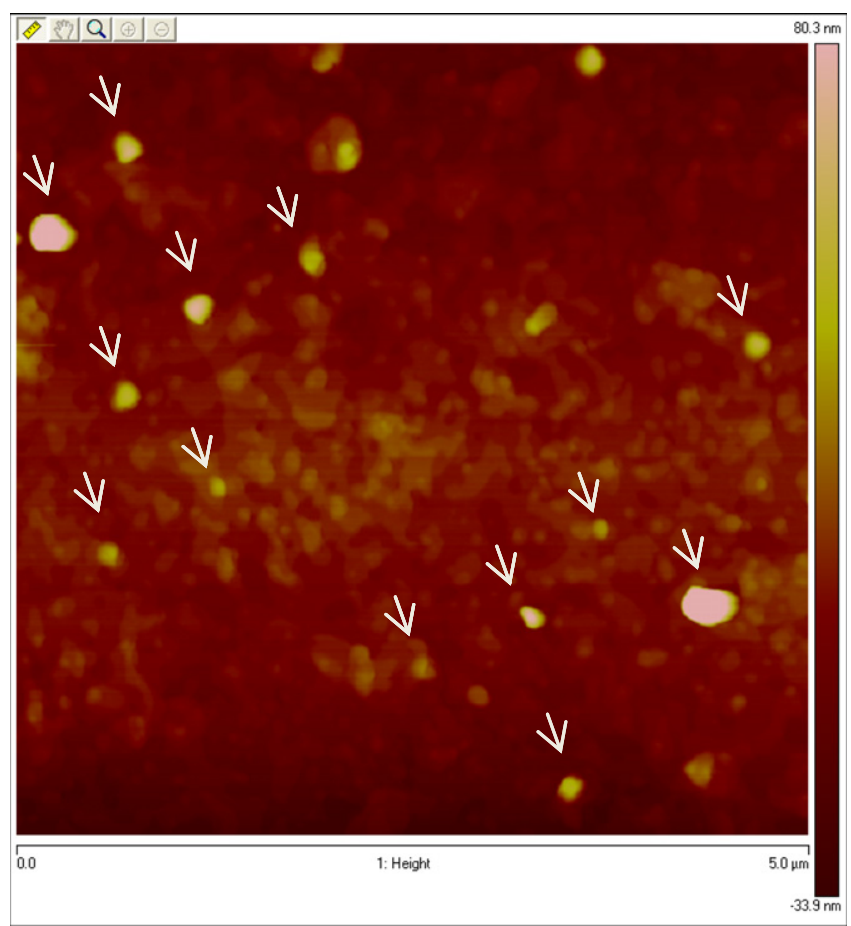

Fig. 3. Atomic force microscopy image of the SLN samples. White arrows are pointing out some cationic SLNs.

at random $(n=20)$ so that their average diameter could be calculated. The result was $230 \mathrm{~nm}( \pm 95 \mathrm{~nm})$. Comparing this with the value given in Section 3.2, this particle size agrees with that found when using the laser diffraction technique. On the one hand, the margin of error was greater for AFM due to the subjectivity involved and the manual calculation of the diameters, while on the other hand the size of the smallest particles was better determined by AFM.

The topographic study revealed that smooth spherical nanometric particles had been obtained.

\subsection{DSC}

The DSC diagrams for all the components in the formulation and their combinations, together with those of the non-lyophilized cationic SLN samples and the different lyophilized samples shaped the results shown in Figs. 4-7.

The DSC curves of all the excipients used in the formulation of the cationic SLNs (Fig. 4) showed that there were no interactions between the products, since the only melting points to be observed were the normal ones. This fact ruled out the possibility that the lyophilization process caused any type of polymorph to form.

A comparison of the DSC diagrams for the two samples shown in Fig. 5 (non-lyophilized and lyophilized without a cryoprotectant) shows differences that indicate an alteration in the characteristics of the sample. There is an exothermic peak in the absence of the cryoprotectant, which demonstrates the degradation of the product. This corresponds with the observation of the broken and/or moved tablet, as well as with the increased difficulty in reconstituting it.

For the cationic SLNs lyophilized with the trehalose cryoprotectant (Fig. 6), the glass transition temperature of the sugar can be seen at approximately $123^{\circ} \mathrm{C}$, while the signal from the SLNs remains at $65-68{ }^{\circ} \mathrm{C}$. This leads us to consider that the process of lyophilization does not alter the quality of the product.

Results obtained from the lyophilized samples with $5 \%$ and $10 \%$ concentrations (Fig. 7) of the mannitol cryoprotectant, some small melting signals could be observed at a temperature close to that of the SLNs. In both cases, interactions or degradation products appeared at approximately $155^{\circ} \mathrm{C}$, which indicated that the use of mannitol did not sufficiently stabilize the cationic SLNs in the lyophilization process. 


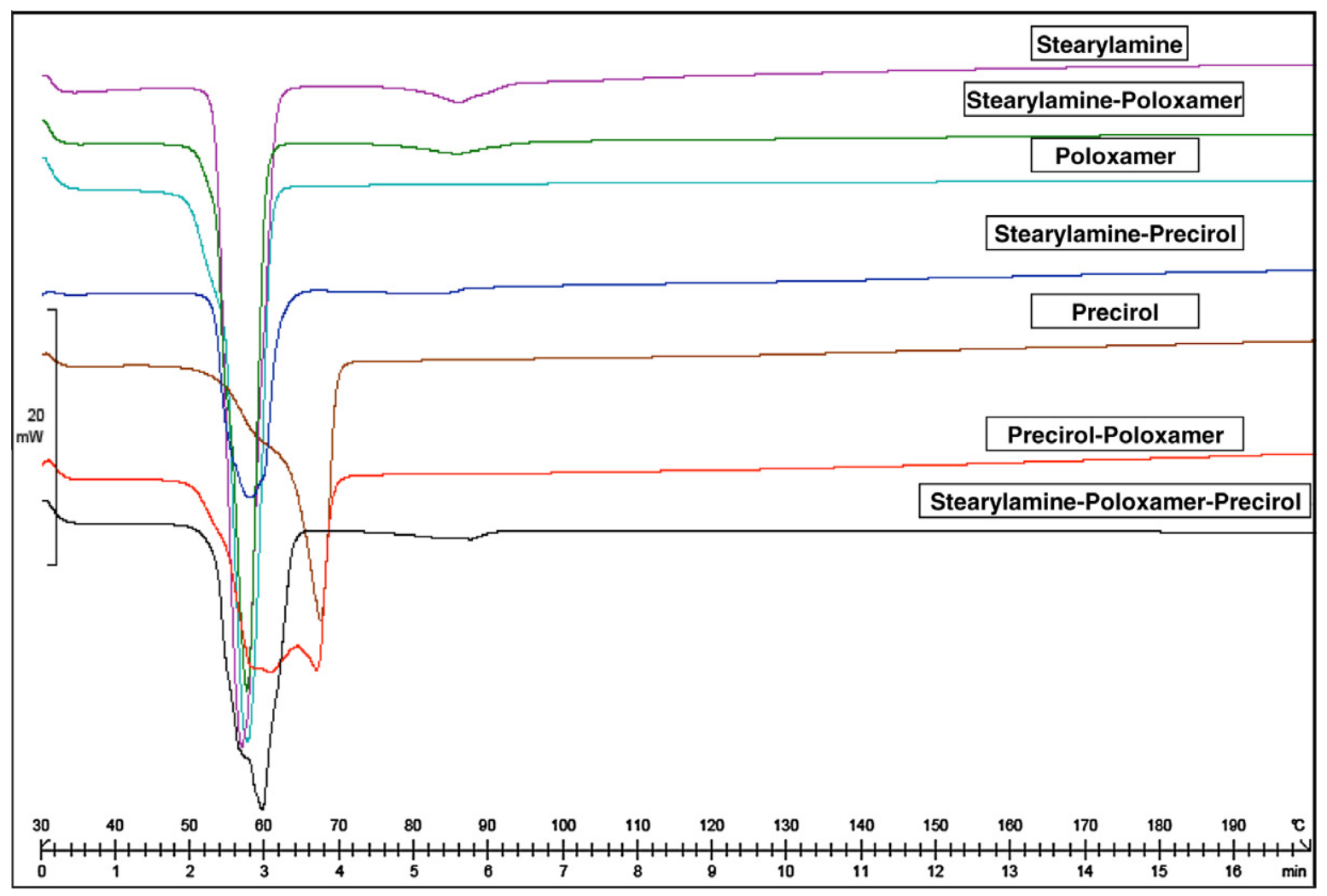

Fig. 4. DSC results for all the components of the formulation of the cationic SLN and their combinations.

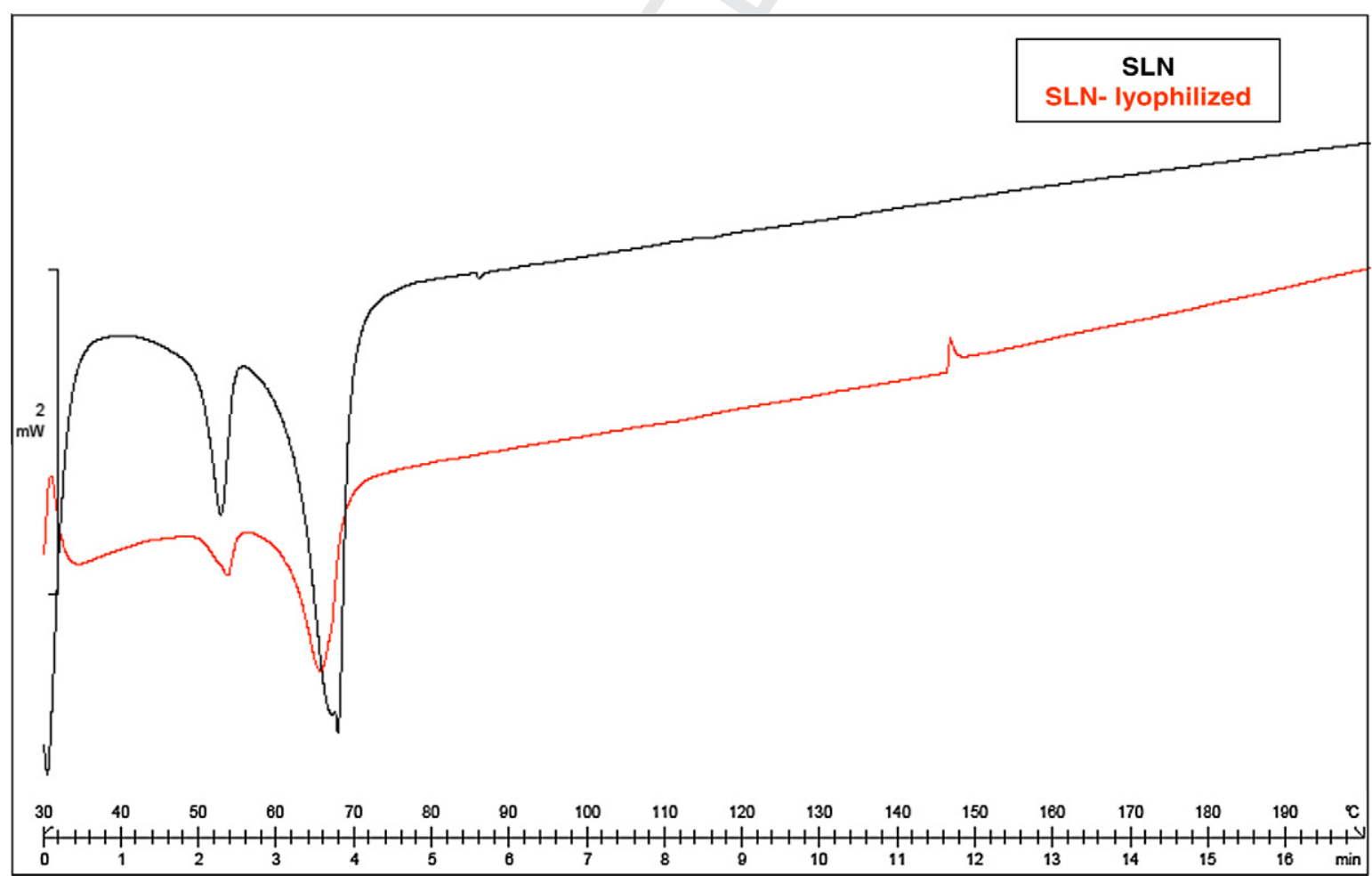

Fig. 5. DSC of cationic SLN samples in the solid state without lyophilization and lyophilized SLNs with no cryoprotectant. 

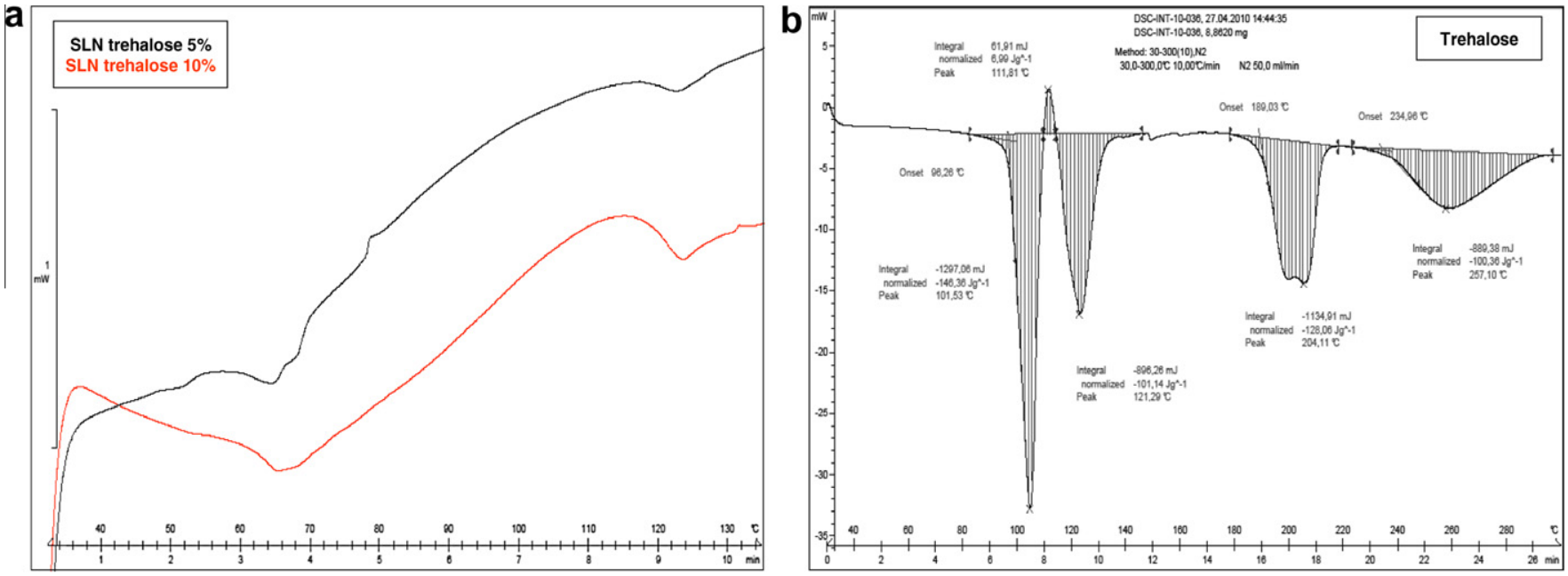

Fig. 6. (a) DSC of lyophilized cationic SLN samples with the cryoprotectant trehalose at a concentration of 5\% and $10 \%$; (b) DSC of trehalose.
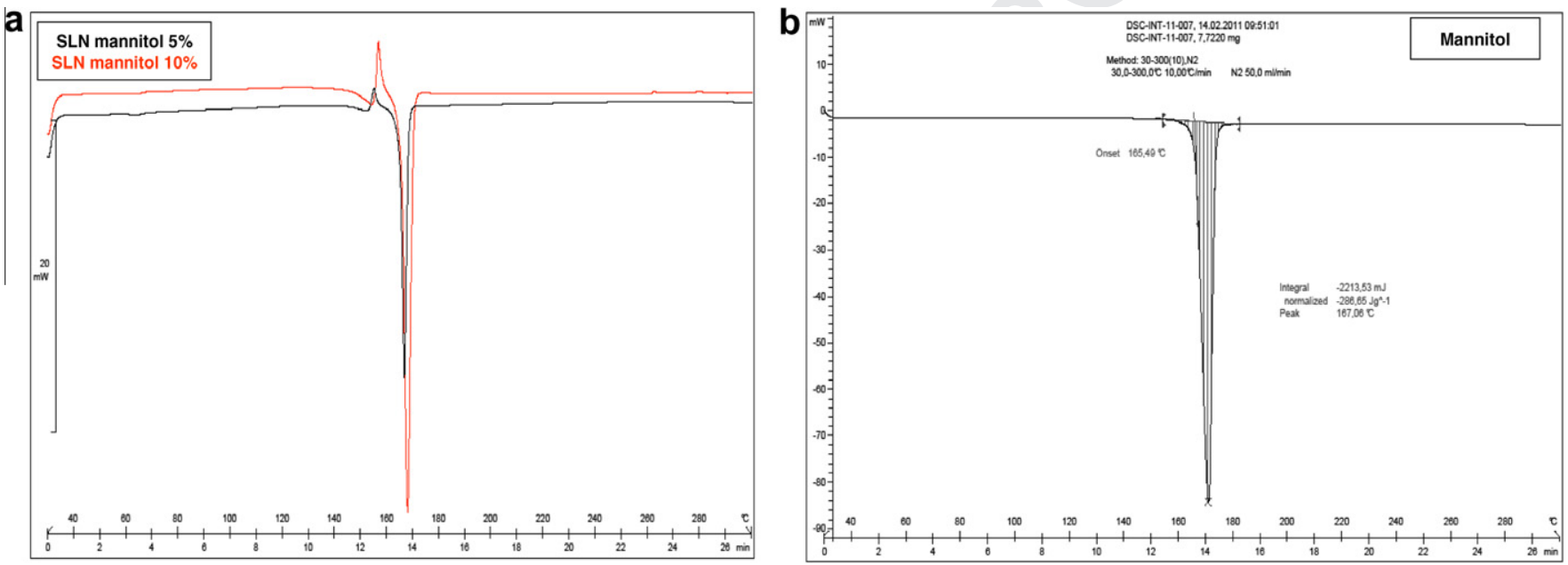

Fig. 7. (a) DSC of lyophilized cationic SLN samples with the cryoprotectant mannitol at a concentration of $5 \%$ and $10 \%$; (b) DSC of mannitol.

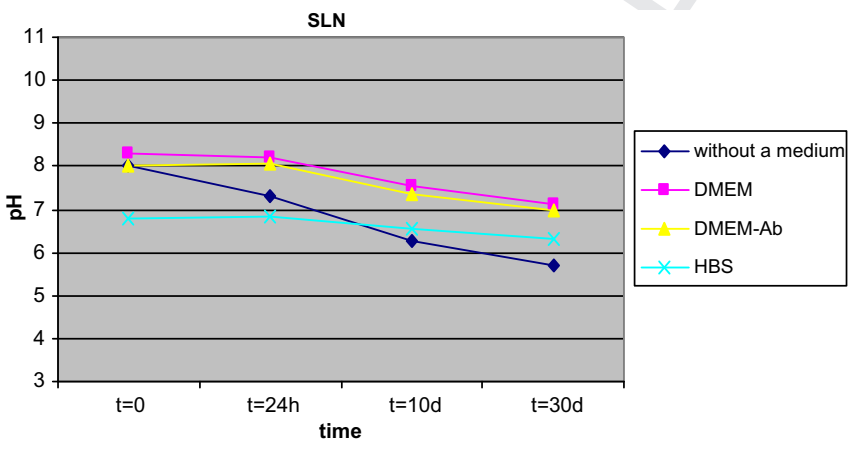

Fig. 8. $\mathrm{pH}$ of the samples as a function of time for the different media.

\subsection{Stability}

Results of the analysis of the samples after different times $(t=0$, $24 \mathrm{~h}, 10$ days and 30 days) at $30^{\circ} \mathrm{C}$ in the determinations of the $\mathrm{pH}$ and surface charge of the medium are shown (Figs. 8 and 9). In order to establish which values are due to the characteristics of the medium itself rather than due to the actual sample, $\mathrm{pH}$ and zetapotential values of the media without the cationic SLNs were taken as a baseline reference (Table 3 ).

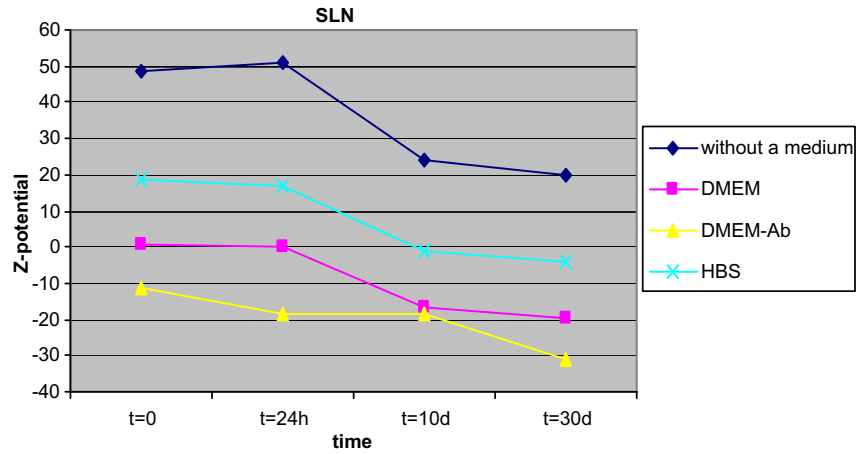

Fig. 9. Zeta-potential values of the samples as a function of time $(t=0,24 \mathrm{~h}, 10$ days and 30 days) for the different media.

Fig. 8 represents pH results. DMEM's pH range is known (6.88.2) and $\mathrm{pH}$ changes indicate medium degradation. In general, a progressive decrease in the value of $\mathrm{pH}$ of the cationic SLNs in all the media can be seen as time increase. This decrease in $\mathrm{pH}$ is more marked for the cationic SLNs without a medium. This trend is also seen for the value of the surface charge (Fig. 9), since a decrease in the zeta-potential value is observed, although it becomes more pronounced after 10 days. 
Table 3

Medium pH and zeta-potential values with no SLNs addition.

\begin{tabular}{llc}
\hline Medium & $\mathrm{pH}$ & Z-potential $(\mathrm{mV})$ \\
\hline DMEM & 8.34 & -7 \\
DMEM-Ab & 8.03 & -12 \\
HBS & 6.87 & -30 \\
\hline
\end{tabular}

$-30 \mathrm{mV}$, since large zeta-potentials facilitate repulsive forces indicating stability, while values in the range between +30 and $-30 \mathrm{mV}$ facilitate the attraction of the particles indicating instability and flocculation.

For all the above mentioned, the cationic SLNs without the addition of a medium can be considered stable up to approximately 10 days. Nevertheless, and bearing in mind that the samples were stored at $30^{\circ} \mathrm{C}+2{ }^{\circ} \mathrm{C}$, the value of the zeta-potential obtained after 30 days was not much lower than that obtained after the samples were stored for 10 days without a medium. Due to the high content in salts of the media used and the negative values of their zetapotentials, these seem to cause problems for the stability of the lipid samples. It would appear that the most suitable medium for preparing fresh samples and being able to work with them over a short period of time (up to $24 \mathrm{~h}$ ) is the HBS medium. a

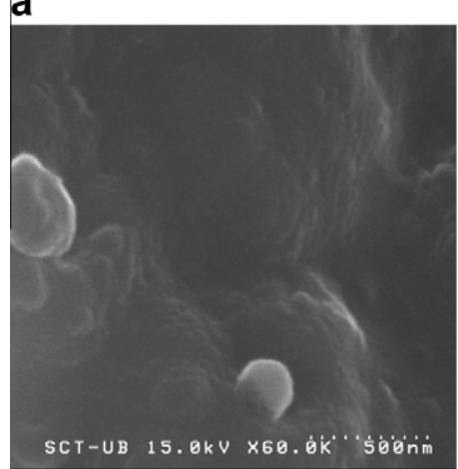

b

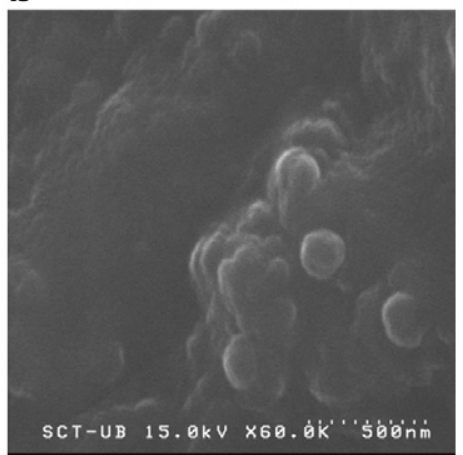

C

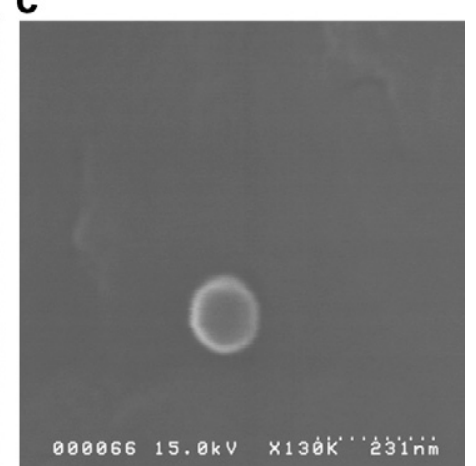

Fig. 10. SEM images for the SLN samples stored at $30 \pm 2{ }^{\circ} \mathrm{C}$ in DMEM medium (a); DMEM-Ab medium (b) and HBS medium (c) from the initial $t=0$.

a

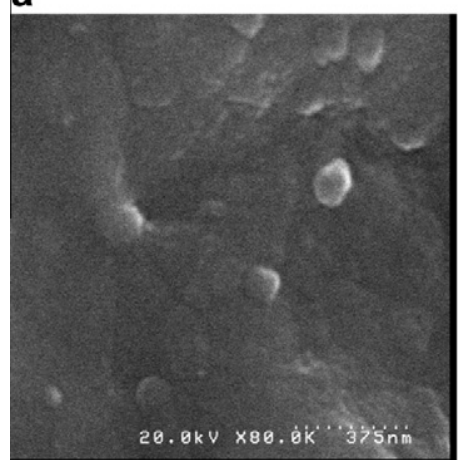

b

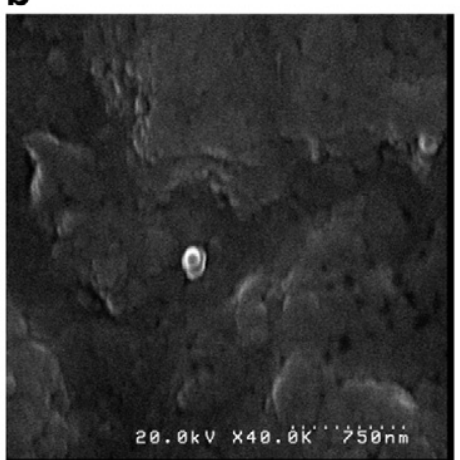

C

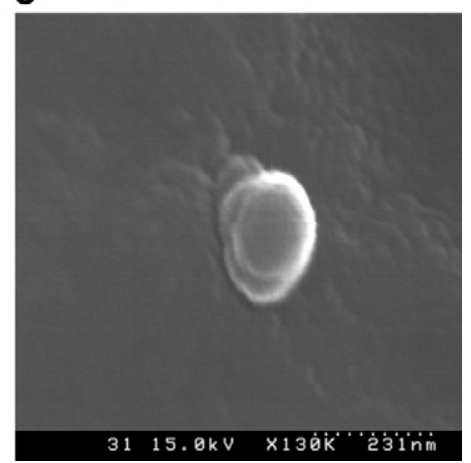

Fig. 11. SEM images for the SLN samples stored at $30 \pm 2{ }^{\circ} \mathrm{C}$ in DMEM medium (a); DMEM-Ab medium (b) and HBS medium (c) $24 \mathrm{~h}$ after formulation.

a

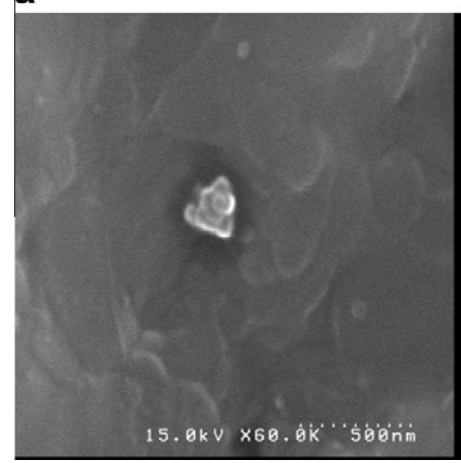

b

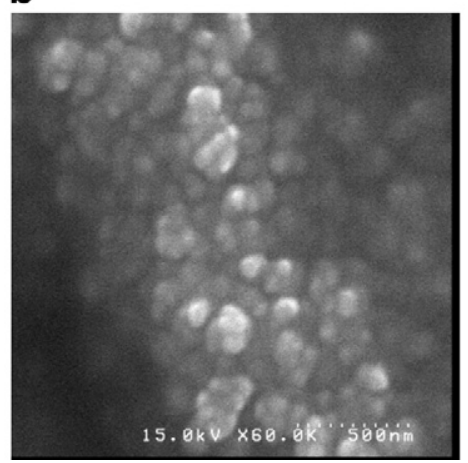

C

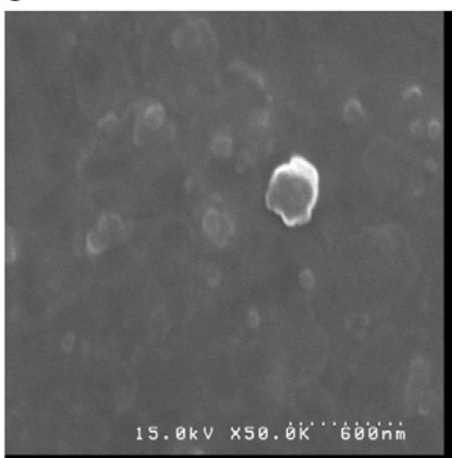

Fig. 12. SEM images for the SLN samples stored at $30 \pm 2{ }^{\circ} \mathrm{C}$ in DMEM medium (a); DMEM-Ab medium (b) and HBS medium (c) 10 days after formulation. 
a

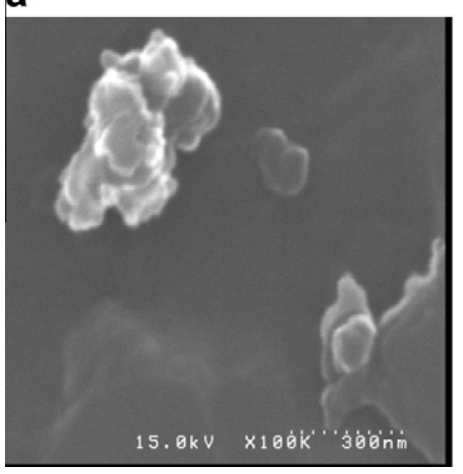

b

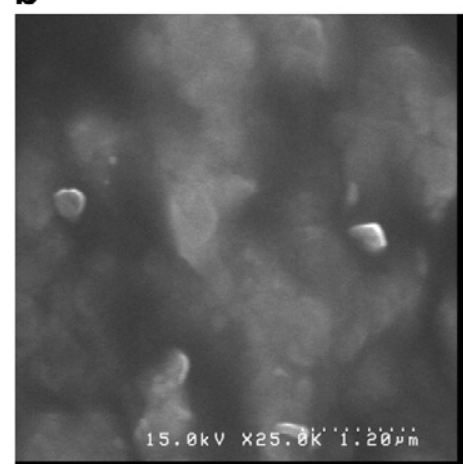

C

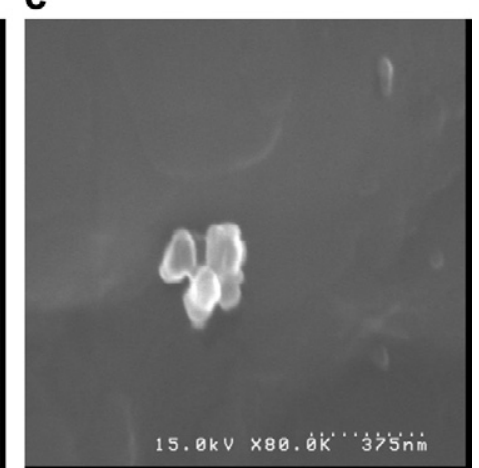

Fig. 13. SEM images for the SLN samples stored at $30 \pm 2{ }^{\circ} \mathrm{C}$ in DMEM medium (a); DMEM-Ab medium (b) and HBS medium (c) 30 days after formulation.

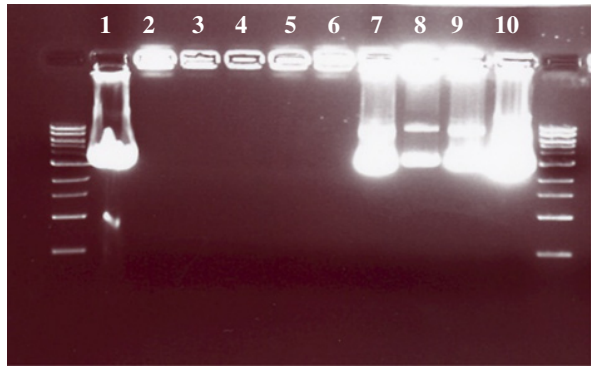

SLN:DNA ratio

1: DNA

2: $15: 1$

3: $10: 1$

4: $7: 1$

5: $6: 1$

6: $5: 1$

7: $4: 1$

8: $3: 1$

9: $2.5: 1$

10: $1: 1$

Fig. 14. Agarose gel electrophoresis of SLN: DNA at different ratios (v/v). DNA: pEFBOSGFP-FF5 (5600 pb approx.) $(25 \mu \mathrm{l}$ of $2 \mu \mathrm{g} / \mu \mathrm{l}$ in each reaction). Ratios: SLN/ DNA vol:vol $(\mu \mathrm{l} / \mu \mathrm{l})$.

The electron microscopy images for the samples stored at $30{ }^{\circ} \mathrm{C} \pm 2{ }^{\circ} \mathrm{C}$ in the DMEM and DMEM-Ab media, right from the initial $t=0$ showed a certain degree of agglomeration of the nanoparticles (Fig. 10a and b). In contrast, in the HBS medium, a greater number of particles that did not agglomerate were observed (Fig. 10c). In general, $24 \mathrm{~h}$ after formulation, the SLNs showed more agglomeration in all media, although to a lesser extent in the HBS (Fig. 11a-c). After 10 days in all media a greater number of aggregates were detected (Figs. 12 and 13), and in some samples, as was the case of the DMEM-Ab medium (Figs. 12b and 13b), no particles were observed that had not formed agglomerations.

\subsection{Agarose gel electrophoresis}

The loading efficiency of the cationic SLNs with respect to the plasmid DNA can be detected from Fig. 14 which shows the results obtained in the agarose gel electrophoresis. Certain concentrations of SLNs can be observed to form bonds with the plasmids; while as the ratio decreases the free DNA signal is observed. Below a proportion of $4: 1$ (SLN:DNA), free DNA is left that has not bonded to the cationic lipid nanoparticles, while the most favorable proportions for bonding to occur are those between 15:1 and 5:1.

\section{Conclusions}

Cationic SLNs were obtained by the method described, with a size of $340 \mathrm{~nm}$ and with a surface charge of approximately $+44 \mathrm{mV}$. Morphological analyses showed that they were smooth spherical nanoparticles and that there were no interactions or polymorphs formed between the products used in the formulation of the nanoparticles.

After the process of lyophilization, resuspension of the lyophilized sample was best achieved when the cryoprotectant trehalose was used at a concentration of $10 \%$; nanoparticles with the same size and surface charge characteristics as those of the initial nanoparticles were obtained. Using a concentration of $5 \%$ of trehalose and after the application of ultrasound in the resuspension of the lyophilized sample these characteristics were also achieved.

Storing the samples at a temperature of $30 \pm 2{ }^{\circ} \mathrm{C}$ in hermetically sealed vials, the fresh cationic SLNs with no addition of a medium were considered to be stable for approximately 10 days.

Of the media used, samples showed greatest stability in the HBS medium for the first $24 \mathrm{~h}$ after formulation. None of the media could be used to guarantee the stability of the fresh cationic SLNs after $24 \mathrm{~h}$ stored at this temperature, as agglomerations of the product formed and physical and chemical changes occurred.

The method developed is suitable for obtaining cationic SLNs that can form a complex with plasmid DNA (lipoplexes).The most efficient proportions for the formation of such lipoplexes is between 15:1 and 5:1 (v/v) of SLN:plasmid DNA.

This study shows that the method developed at this point produces cationic SLNs that are effectively loaded with plasmid DNA.

\section{References}

Aguar Fernandez, M.P., Hullmann, A., 2007. A boost for safer nanotechnology. Nano. Q3 409 Today 2. http://dx.doi.org/10.1016/S1748-0132(07)70037-3, 56-56.

Battaglia, L., Gallarate, M., Cavalli, R., Trotta, M., 2010. Solid lipid nanoparticles produced through a coacervation method. J. Microencapsul. 27, 78-85. http:// dx.doi.org/10.3109/02652040903031279.

Blasi, P., Giovagnoli, S., Schoubben, A., Ricci, M., Rossi, C., 2007. Solid lipid nanoparticles for targeted brain drug delivery. Adv. Drug Deliv. Rev. 59, 454477. http://dx.doi.org/10.1016/j.addr.2007.04.011.

Bondi', M.L., Azzolina, A., Craparo, E.F., Lampiasi, N., Capuano, G., Giammona, G., Cervello, M., 2007. Novel cationic solid-lipid nanoparticles as non-viral vectors for gene delivery. J. Drug Target. 15, 295-301. http://dx.doi.org/10.1080/ 10611860701324698

Borchard, G., 2001. Chitosans for gene delivery. Adv. Drug Deliv. Rev. 52, 145-150. http://dx.doi.org/10.1016/S0169-409X(01)00198-3.

Carneiro-da-Cunha, M.G., Cerqueira, M.A., Souza, B.W.S., Teixeira, J.A., Vicente, A.A 2011. Influence of concentration, ionic strength and $\mathrm{pH}$ on zeta potential and mean hydrodynamic diameter of edible polysaccharide solutions envisaged for multinanolayered films production. Carbohydr. Polym. 85, 522-528. http:// dx.doi.org/10.1016/j.carbpol.2011.03.001.

Corsi, K., Chellat, F., Yahia, L., Fernandes, J.C., 2003. Mesenchymal stem cells, MG63 and HEK293 transfection using chitosan-DNA nanoparticles. Biomaterials 24 1255-1264. http://dx.doi.org/10.1016/S0142-9612(02)00507-0.

Davis, M.E., 2002. Non-viral gene delivery systems. Curr. Opin. Biotechnol. 13, 128 131. http://dx.doi.org/10.1016/S0958-1669(02)00294-X.

De Laporte, L., Cruz Rea, J., Shea, L.D., 2006. Design of modular non-viral gene therapy vectors. Biomaterials 27, 947-954. http://dx.doi.org/10.1016 j.biomaterials.2005.09.036.

del Pozo-Rodríguez, A., Delgado, D., Solinís, M.A., Gascón, A.R., Pedraz, J.L., 2007 Solid lipid nanoparticles: formulation factors affecting cell transfection capacity. Int. J. Pharm. 339, 261-268. http://dx.doi.org/10.1016/ j.ijpharm.2007.03.015.

del Pozo-Rodríguez, A., Delgado, D., Solinís, M.A., Gascón, A.R., Pedraz, J.L., 2008 Solid lipid nanoparticles for retinal gene therapy: transfection and intracellula trafficking in RPE cells. Int. J. Pharm. 360, 177-183. http://dx.doi.org/10.1016/ j.ijpharm.2008.04.023. 
del Pozo-Rodríguez, A., Delgado, D., Solinís, M.Á., Pedraz, J.L., Echevarría, E Rodríguez, J.M., Gascón, A.R., 2010. Solid lipid nanoparticles as potential tools for gene therapy: in vivo protein expression after intravenous administration. Int. J. Pharm. 385, 157-162. http://dx.doi.org/10.1016/j.ijpharm.2009.10.020.

Dowling, A.P., 2004. Development of nanotechnologies. Mater. Today 7, 30-35. http://dx.doi.org/10.1016/S1369-7021(04)00628-5.

Duarte, S., Fanceca, H., Pedroso de Lima, M.C., 2012. Folate-associated lipoplexes mediate efficient gene delivery and potent antitumoral activity in vitro and in vivo. Int. J. Pharm. 423, 365-377. http://dx.doi.org/10.1016/ j.ijpharm.2011.12.035.

European Pharmacopoeia, seventh ed. (7.3), 2012. Council of Europe, Strasbourg, France (2.9.31)

Ewert, K., Ahmad, A., Evans, H.M., Safinya, C.R., 2005. Cationic lipid-DNA complexes for non-viral gene therapy: relating supramolecular structures to cellular pathways. Expert Opin. Biol. Ther. 5, 33-53. http://dx.doi.org/10.1517/ 14712598.5.1.33.

Faneca, H., Simões, S., Pedroso de Lima, M.C., 2002. Evaluation of lipid-based reagents to mediate intracellular gene delivery. Biochim. Biophys. Acta 1567, 23-33. http://dx.doi.org/10.1016/S0005-2736(02)00545-X.

Ferrer-Miralles, N., Vázquez, E., Villaverde, A., 2008. Membrane-active peptides for non-viral gene therapy: making the safest easier. Trends Biotechnol. 26, 267275. http://dx.doi.org/10.1016/j.tibtech.2008.02.003.

Gasco, M.R., 1993. Method of producing solid lipid microspheres having a narrow distribution, US patent $5,250,236$.

He, C., Tabata, Y., Gao, J., 2010. Non-viral gene delivery carrier and its threedimensional transfection system. Int. J. Pharm. 386, 232-242. http://dx.doi.org/ 10.1016/j.jpharm.2009.11.006.

Joshi, M.D., Müller, R.H., 2009. Lipid nanoparticles for parenteral delivery of actives. Eur. J. Pharm. Biopharm. 71, 161-172. http://dx.doi.org/10.1016/j.ejpb.2008.09.003.

Ledley, F.D., 1996. Pharmaceutical approach to somatic gene therapy. Pharm. Res. $13,1595-1614$

Li, S., Huang, L., 2007. Non-viral is superior to viral gene delivery. J. Control. Release 123, 181-183. http://dx.doi.org/10.1016/j.jconrel.2007.09.004

Liang, Y., Liu, Z., Shuai, X., Wang, W., Liu, J., Bi, W., Wang, C., Jing, X., Liu, Y., Tao, E., 2012. Delivery of cationic polymer-siRNA nanoparticles for gene therapies in neural regeneration. Biochem. Biophys. Res. Commun. 421, 690-695. http:// dx.doi.org/10.1016/j.bbrc.2012.03.155.

Liao, D.L., Wu, G.S., Liao, B.Q., 2009. Zeta potential of shape-controlled $\mathrm{TiO}_{2}$ nanoparticles with surfactants. Colloids Surf., A 348, 270-275. http://dx.doi.org/ 10.1016/j.colsurfa.2009.07.036.

Marengo, E., Cavalli, R., Caputo, O., Rodriguez, L., Gasco, M.R., 2000. Scale-up of the preparation process of solid lipid nanospheres. Part I. Int. J. Pharm. 205, 3-13. http://dx.doi.org/10.1016/S0378-5173(00)00471-3.

Martins, S., Tho, I., Reimold, I., Fricker, G., Souto, E., Ferreira, D., Brandl, M., 2012. Brain delivery of camptothecin by means of solid lipid nanoparticles: formulation design, in vitro and in vivo studies. Int. J. Pharm. 439, 49-62. http://dx.doi.org/10.1016/j.ijpharm.2012.09.054.

Medina, C., Santos-Martinez, M.J., Radomski, A., Corrigan, O.I., Radomski, M.W. 2007. Nanoparticles: pharmacological and toxicological significance. Br. J. Pharmacol. 150, 552.

Mehnert, W., Mäder, K., 2012. Solid lipid nanoparticles: production, characterization and applications. Adv. Drug Deliv. Rev. 64, 83-101. http:// dx.doi.org/10.1016/jaddr.2012.09.021.

Mora-Huertas, C.E., Fessi, H., Elaissari, A., 2010. Polymer-based nanocapsules for drug delivery. Int. J. Pharm. 385, 113-142. http://dx.doi.org/10.1016/ j.ijpharm.2009.10.018.
Müller, M.R., 1991. Colloidal carriers for controlled drug delivery and targetingmodification, characterization and in vivo distribution. Wissenschaftliche Verlagsgesellschaft Stuttgart. CRC Press, Boca Raton, 379.

Müller, R.H., Mäder, K., Gohla, S., 2000. Solid lipid nanoparticles (SLNs) for controlled drug delivery - a review of the state of the art. Eur. J. Pharm. Biopharm. 50, 161-177. http://dx.doi.org/10.1016/S0939-6411(00)00087-4.

Nishikawa, M., Hashida, M., 2002. Nonviral approaches satisfying various requirements for effective in vivo gene therapy. Biol. Pharm. Bull. 25, 275-283.

Nowack, B., Bucheli, T.D., 2007. Occurrence, behavior and effects of nanoparticles in the environment. Environ. Pollut. 150, 5-22. http://dx.doi.org/10.1016/ j.envpol.2007.06.006.

Olbrich, C., Bakowsky, U., Lehr, C., Müller, R.H., Kneuer, C., 2001. Cationic solid-lipid nanoparticles can efficiently bind and transfect plasmid DNA. J. Control. Release 77, 345-355. http://dx.doi.org/10.1016/S0168-3659(01)00506-5.

Pedersen, N., Hansen, S., Heydenreich, A.V., Kristensen, H.G., Poulsen, H.S., 2006. Solid lipid nanoparticles can effectively bind DNA, streptavidin and biotinylated ligands. Eur. J. Pharm. Biopharm. 62, 155-162. http://dx.doi.org/10.1016/ j.ejpb.2005.09.003.

Richardson, S.C.W., Kolbe, H.V.J., Duncan, R., 1999. Potential of low molecular mass chitosan as a DNA delivery system: biocompatibility, body distribution and ability to complex and protect DNA. Int. J. Pharm. 178, 231-243. http:// dx.doi.org/10.1016/S0378-5173(98)00378-0.

Rogers, M.-L., Rush, R.A., 2012. Non-viral gene therapy for neurological diseases, with an emphasis on targeted gene delivery. J. Control. Release 157, 183-189. http://dx.doi.org/10.1016/j.jconrel.2011.08.026.

Suñé, C. Hayashi, T., Liu, Y., Lane, W.S., Young, R.A., Garcia-Blanco, M.A, 1997. CA150, a nuclear protein associated with the RNA polymerase II holoenzyme, is involved in Tat-activated human immunodeficiency virus type 1 transcription. Mol. Cell. Biol. 17, 6029-6039.

Tabatt, K., Kneuer, C., Sameti, M., Olbrich, C., Müller, R.H., Lehr, C., Bakowsky, U., 2004. Transfection with different colloidal systems: comparison of solid lipid nanoparticles and liposomes. J. Control. Release 97, 321-332. http://dx.doi.org/ 10.1016/j.jconrel.2004.02.029.

Vighi, E., Ruozi, B., Montanari, M., Battini, R., Leo, E., 2007. Re-dispersible cationic solid lipid nanoparticles (SLNs) freeze-dried without cryoprotectors: Characterization and ability to bind the pEGFP-plasmid. Eur. J. Pharm. Biopharm. 67, 320-328. http://dx.doi.org/10.1016/j.ejpb.2007.02.006.

Wang, Y., Zhu, L., Dong, Z., Xie, S., Chen, X., Lu, M., Wang, X., Li, X., Zhou, W., 2012. Preparation and stability study of norfloxacin-loaded solid lipid nanoparticle suspensions. Colloids Surf., B 98, 105-111. http://dx.doi.org/10.1016/ j.colsurfb.2012.05.006.

Wissing, S.A., Kayser, O., Müller, R.H., 2004. Solid lipid nanoparticles for parenteral drug delivery. Adv. Drug Deliv. Rev. 56, 1257-1272. http://dx.doi.org/10.1016/ j.addr.2003.12.002.

Wong, H.L., Wu, X.Y., Bendayan, R., 2012. Nanotechnological advances for the delivery of CNS therapeutics. Adv. Drug Deliv. Rev. 64, 686-700. http:// dx.doi.org/10.1016/j.addr.2011.10.007.

Wu, N., Ataai, M.M., 2000. Production of viral vectors for gene therapy applications. Curr. Opin. Biotechnol. 11, 205-208. http://dx.doi.org/10.1016/S09581669(00)00080-X

Zweck, A., Bachmann, G., Luther, W., Ploetz, C., 2008. Nanotechnology in Germany: from forecasting to technological assessment to sustainability studies. J. Clean. Prod. 16, 977-987. http://dx.doi.org/10.1016/j.jclepro.2007.04.016. 